\title{
Indicator Device
}

National Cancer Institute

\section{Source}

National Cancer Institute. Indicator Device. NCI Thesaurus. Code C50001.

A device designed to show an operating condition of a system or to attract attention. 